\title{
Effectiveness of Digital Gaming in Education for Sustainable Development
}

\author{
Jürgen Paul $^{1 *}$, Richard Fry ${ }^{2}$, Moritz Schneider ${ }^{1}$ \\ ${ }^{I}$ Department of Science Education, University of Bamberg, Markusplatz 3 (Noddack-Haus) \\ 96047 Bamberg, Germany \\ ${ }^{2}$ Coburg University of Applied Sciences, Friedrich-Streib-Strasse 296450 Coburg, Germany
}

*Corresponding Author: Jürgen Paul, Department of Science Education, University of Bamberg, Markusplatz 3 (Noddack-Haus)

\begin{abstract}
Education for Sustainable Development (ESD) is a vital topic for schools and society. In our study, we investigated how a digital educational game can help to understand the complex interrelationships of sustainable actions. For this purpose, the educational game "DiLeNa" was developed and then evaluated in school practice. DiLeNa simulates a household in which the residents are supposed to live considering health and sustainability perspectives. To analyze the learning processes of the participating 9-10 years old students, guided interviews were conducted. Student conceptions were derived using qualitative content analysis. The results indicate that the learning processes triggered can primarily be traced back to the immediate feedback on sustainability-relevant actions during the game. In the real world, the consequences of those actions would be mostly inaccessible and incomprehensible because of their complexity and their long-term impact. Therefore, simulation games open up valuable opportunities to easily implement ESD in elementary school lessons.
\end{abstract}

Key words: Education for Sustainable Development, serious games, digital learning

Abbreviations: $U N=$ United Nations, ESD = Education for Sustainable Development

\section{INTRODUCTION}

In 2019 the Swedish activist Greta Thunberg led her "school strikes for the climate" to the global movement "Fridays for Future" and thus attracted a wide audience and considerable attention to the topic of sustainability. However, from 2005 to 2014, with the UN Decade of Education for Sustainable Development (ESD), the United Nations had already committed to anchoring the principles of sustainability in education systems. Further global and national ESD programs followed. In the meantime, national curricula in many countries address and include content related to sustainability.

Although there has been a long tradition of environmental education in German schools [1], the multiple perspectives and the complexity of sustainability, as well as the associated methodological requirements are still a major challenge for teachers. Several studies state that the influence of school education on environmental action is only minor [2]. Since environmental action can most likely be initiated through action-oriented learning, the focus on action and experience must be given priority at school [3]. Neurobiological studies also show that, regardless of objective significance, the human brain only reacts to that which affects us emotionally and appears to be important to us based on our own subjective assessment [4]. Concrete and achievable goals motivate to action. However, the goals of education for sustainable development are often on an abstract level and the link between action and result is long-term, and not directly apparent. Knowledge alone does not principally generate corresponding behavior ("Knowledge-Action-Gap" [5]).

The corona pandemic in 2020 showed the global community that digital media is not only trendy and useful, but can also be life-saving. As a result of the lockdown, school buildings were closed and there was an urgent need for digital tools for home schooling - despite the extensive discussion of the previous years on the use of digital media in teaching. However, several empirical studies generated 
useful findings of how effective digital media can be in teaching [6]. The development of scenarios that combine informal learning contexts outside of school with formal learning processes seems to be very promising. This is confirmed by initial experiences with programs that integrate digital learning games into regular school lessons [7].

The increasing number of publications of research projects on digital learning games indicates that an area is developing here with great potential both for educational research and for school practice [8]. The terms used in this context partly overlap in their meaning and are not always sharply demarcated from one another, e.g. digital game-based learning, serious games, gamification, edutainment, elearning $[9 ; 10]$. In game-based learning, content is conveyed on the basis of a game or a simulation. This principle is implemented in serious games such as the digital educational game for sustainability "DiLeNa" presented here. These serious games are supposed to open up promising ways to convey ESD content $[11 ; 12]$.

One of the two fundamental ideas of the project was to link the required focus on action and experience with the concept of sustainability considering young people's affinity for digital media. The second basic idea was to design a digital educational game that can be integrated into school lessons in a formal learning context and also enables informal engagement with the topic outside of school. For this purpose, the educational game "DiLeNa" was developed in cooperation with an established game company and then evaluated in school practice. The scientific evaluation addressed the following research question: What can a digital educational game contribute to ESD in elementary school by linking knowledge and (digital) action in combination with immediate feedback?

\section{THEORY AND METHODOLOGY}

\subsection{Theoretical Background}

Our understanding of learning is based on constructivism [13] and a revised conceptual change approach $[14 ; 15]$, that considers a situated perspective [16]. We see students as individual learners who construct their knowledge in an active and self-regulated procedure on the basis of existing conceptions. In accordance with this, the learning process cannot be controlled completely by external factors, but can be initiated by learning environments. The students' conceptions derived from everyday experiences can be beneficial or obstructive for learning [17]. Thus, we understand conceptual changes as reconstructions of conceptions [18], where conceptions can be further developed, changed, or newly formed.

\subsection{Game content}

The game "DiLeNa" aims to convey sustainable consumption through the example of human nutrition. As such, it addresses economic, ecological and social perspectives which are the main indicators used during the gameplay. These three perspectives of human nutrition also clearly structure and link the 17 sustainable development goals [cf. „SDG wedding cake“; 19].The target group of the game is students mainly from elementary school. Sustainable and healthy nutrition is curriculum content from grades 3-5 (8-11 years old). The game can be integrated into normal school lessons as well as used for home schooling or informal learning at home. The complex relationships involved in sustainable actions should be simulated in the game and positive feedback should increase the emotional significance and self-efficacy [20]. These positive (game) experiences should then be transferred to the actions of the student's real life.

Game scenario: In the game, the player is supposed to help his great-aunt Lilly with housekeeping over the summer holidays. To do this, he buys groceries in the store, tends the garden and looks after the chickens. In the garden, he can grow vegetables or pick cherries. The player takes care of himself by eating a broad variety of food. The preparation or eating of food causes packaging waste. This waste must be correctly assigned to the various garbage cans (waste separation). Occasionally, the learner is asked different questions in a quiz: If answered correctly, he earns additional household money. His actions have a direct effect on the game indicators "personal wellbeing", "environment" (ecology), "society" (social) and "economy" (cf. Fig. 1). The game simulation is based on a very simple modeling of dependencies (e.g. imported foods such as bananas have a worse ecological impact than regional foods such as apples). At the end of the game, the player receives a detailed report. 


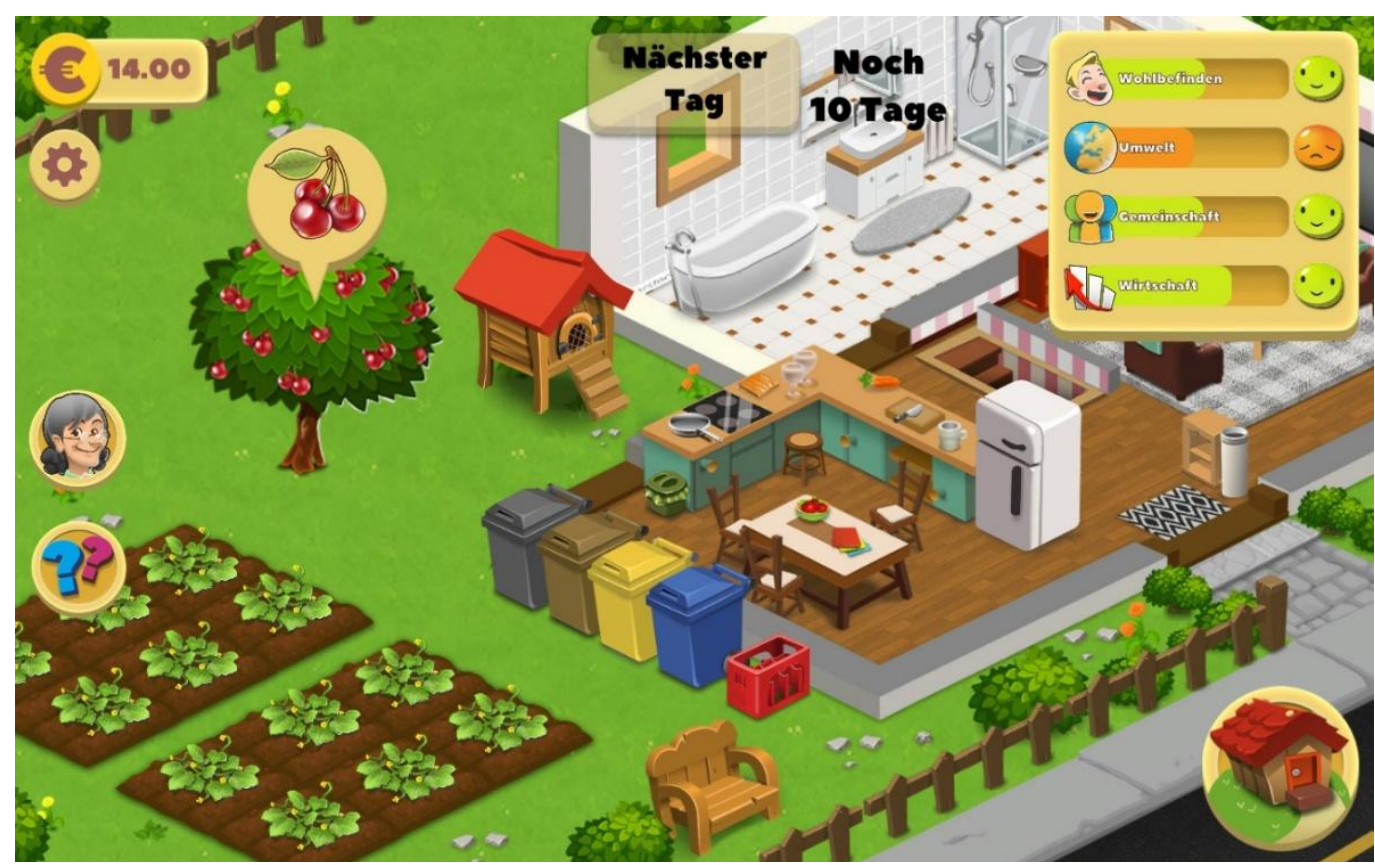

Fig1. Screenshot of the digital educational game used, which addresses sustainable consumption through the example of human nutrition.

\subsection{Research Methodology}

To investigate students' conceptions and any possible changes, guided individual interviews were chosen. The interview guideline used integrates two methodological approaches: Firstly problemoriented, open and half-open questions to collect current conceptions and secondly the retrospective query on the learning process [21]. The guideline was structured in four parts: (1) general questions about the game, (2) general questions about the participant's conceptions of sustainability, (3) concrete examples of the game's content, (4) conceptual changes. For the present research project, ten individual interviews were conducted with students from an elementary school (4th grade, 9-10 years old; 5 female, 5 male). The interviews each lasted about 20-25 minutes. The probands were randomly selected from a group of 21 volunteers. All personalized data were made anonymous. The interviews were captured using a voice recorder. The interrelationship between questions and answers was validated by two different researchers based on qualitative content analysis [22]. The student statements were summarized in tables, with a distinction being made between the retrospectively named conceptions and the current conceptions. By comparing these conceptions, conclusions could be drawn about the learning process and possible causes derived.

\section{RESUltS}

\subsection{Students' Conceptions About Sustainable Nutrition}

An example is quoted to represent a typical student game experience and the associated statement about garbage (original transcript excerpt, retrospective query on the learning process):

Interviewer: "What did you know about it before you got involved with the educational game?"

Emily (10 years-old): "My mom told me that the foil would go in the yellow bin. (...) For me it was all rubbish. And you throw away rubbish because you can't do anything with it. (...) Now I know how to properly separate the waste and why. So that you can reuse it."

Interviewer: "Earlier you said that you had learned something. Please summarize. What did you learn about sustainability?"

Emily: "I've learned that it's good for the environment when you separate the garbage. The game showed me how to do it. (...)"

For Emily, garbage used to be worthless. Through playing the game, it became clear to her that sorting the garbage correctly helps to preserve the environment. Emily's change of mind thus represents the learning process from the conception that garbage can no longer be used to the conception that you have to separate garbage in order to recycle it. 
The students saw the content covered by the educational game in a wide-ranging manner. A total of 26 different concepts were found, which were assigned to five categories (cf. Tab. 1). These five categories, which were subsequently determined on the basis of the data, are: regional products, meat consumption, organic products \& self-sufficiency, waste separation \& recycling, sustainability in general. The concepts mentioned most frequently were \# 5, \# 11, \# 18, \# 24 and \# 26 (bold in Table 1).

Table1. Concepts about sustainability and related issues

\begin{tabular}{|c|c|c|c|}
\hline Category & \# & Derived concepts & Incidence \\
\hline \multirow{7}{*}{$\begin{array}{l}\text { Sustainabilty in } \\
\text { general }\end{array}$} & 1 & You behave sustainably when you save resources. & 5 \\
\hline & 2 & I have to divide up my money or I will run out of money. & 3 \\
\hline & 3 & Sustainability means that you reuse things. & 3 \\
\hline & 4 & Sustainability is synonymous with environmental protection. & 5 \\
\hline & 5 & $\begin{array}{l}\text { In order to act sustainably, you have to weigh up the } \\
\text { three perspectives of environment, economy and social } \\
\text { issues. }\end{array}$ & 6 \\
\hline & 6 & $\begin{array}{l}\text { Sustainability means that in the future the earth will be left to } \\
\text { people as it was before. }\end{array}$ & 3 \\
\hline & 7 & Sustainability is something very worth striving for. & 4 \\
\hline \multirow[t]{6}{*}{ Regional products } & 8 & I prefer products because of their price. & 5 \\
\hline & 9 & I prefer products from the region. & 4 \\
\hline & 10 & $\begin{array}{l}\text { Products from my home country are good for the } \\
\text { environment. }\end{array}$ & 3 \\
\hline & 11 & $\begin{array}{l}\text { Products from the region do not travel long distances, } \\
\text { which is why (also) fewer exhaust gases are emitted. }\end{array}$ & 7 \\
\hline & 12 & Regional products create jobs nearby. & 2 \\
\hline & 13 & When I buy regional products, I support the local economy. & 3 \\
\hline \multirow[t]{2}{*}{ Meat consumption } & 14 & $\begin{array}{l}\text { I eat little meat because the animals are poorly kept and } \\
\text { killed. }\end{array}$ & 3 \\
\hline & 15 & $\begin{array}{l}\text { Plant-based foods are more sustainable than products made } \\
\text { from meat. }\end{array}$ & 3 \\
\hline \multirow{4}{*}{$\begin{array}{l}\text { Organic products \& } \\
\text { self-sufficiency }\end{array}$} & 16 & Organic products contain better nutrients. & 2 \\
\hline & 17 & $\begin{array}{l}\text { Organic products are more sustainable than conventional } \\
\text { ones. }\end{array}$ & 3 \\
\hline & 18 & $\begin{array}{l}\text { Organic products are more environmentally compatible } \\
\text { in their production. }\end{array}$ & 6 \\
\hline & 19 & $\begin{array}{l}\text { When I grow food by myself, I can harvest it and grow it } \\
\text { again using part of the harvest. }\end{array}$ & 4 \\
\hline \multirow{7}{*}{$\begin{array}{l}\text { Waste separation \& } \\
\text { recycling }\end{array}$} & 20 & Waste is bad for animals and for the environment. & 4 \\
\hline & 21 & Waste can no longer be used. & 4 \\
\hline & 22 & Separating waste is good for the environment. & 5 \\
\hline & 23 & If I separate the waste, I feel better. & 3 \\
\hline & 24 & You have to separate the waste so that you can reuse it. & 7 \\
\hline & 25 & $\begin{array}{l}\text { The waste is separated and sorted, but in the end only } \\
\text { incinerated. }\end{array}$ & 2 \\
\hline & 26 & $\begin{array}{l}\text { With recycling, old is made into new, i.e. the waste is } \\
\text { reused. }\end{array}$ & 6 \\
\hline
\end{tabular}

Tab1. The derived concepts mentioned by the 10 probands. The five categories were determined subsequently based on the data. The concepts in bold were named by 6 or 7 of 10 probands (incidence).

\subsection{Students' Conceptual Changes}

Eight of the ten probands reported that their conceptions changed while they were working with the educational game. Two of the learners did not develop their already partially correct conceptions any further. Conceptual changes occurred in all five categories. The retrospective survey not only made it possible to identify the conceptual development, but also to clarify the associated cause-effect relationships of the underlying learning processes. In the following, learning processes are described for three selected conceptual changes (Fig. 2a-c).

The idea of paying attention to the place of origin when shopping for food was completely new for many students. In the game, for example, bananas were recognized as imported food with long 
transport routes, while apples are usually regional products. In this way, the linking concept \# 11 was developed that regional products are more environmentally friendly due to the shorter transport routes. With this background, the conceptions typically changed from concept \# 8 to concept \# 9 (Fig. $2 \mathrm{a} ; 4$ out of 5 probands, Table 1). The reason given for this was that the purchase of products had an immediate and visible effect on the main indicators in the game. During another game activity, the player occasionally had to sort the accumulated garbage. Immediately after sorting the garbage, the player was shown what he had done wrong. This direct feedback, combined with the information that correctly separated waste is suitable for recycling, was named as the reason for the change from concept \# 20 to concept \# 24 (Fig. 2b).

The term sustainability was often equated with environmental protection (concept \# 4). Typically, after working with the learning game, this concept was changed to the concept that sustainability equally includes the three different perspectives of ecology, economy and social issues and one sometimes has to weigh between these perspectives (concept \# 5). According to the probands, this change resulted from the effects of their own actions on the three sustainability indicators visualized in the game (Fig. 2c).

\section{a) Regional products}

\section{The purchase of products immediately had an impact on the sustainability indicators. So the game showed me that regional products are more sustainable.}

\section{I prefer products because of their price. \\ I prefer products from the region.}

\section{b) Waste separation \& recycling}

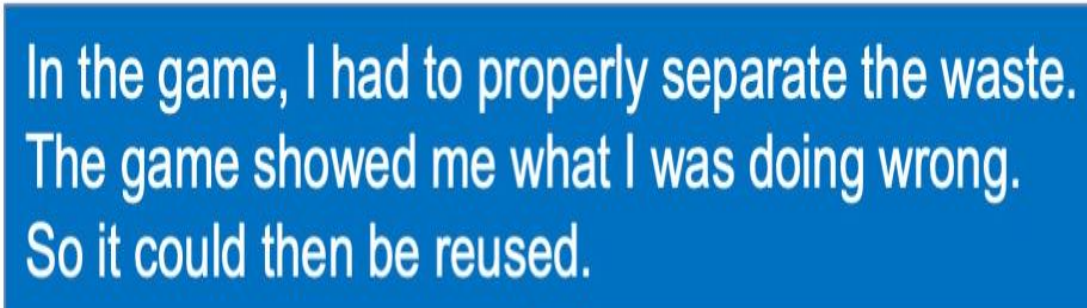

\section{Waste is bad for animals and for the environment.}

You have to separate the waste so that you can reuse it. 


\section{c) Sustainability in general}

\section{The game had indicators for environment, society, and economy. So the game showed me that there is usually no way that is equally good for all perspectives.}

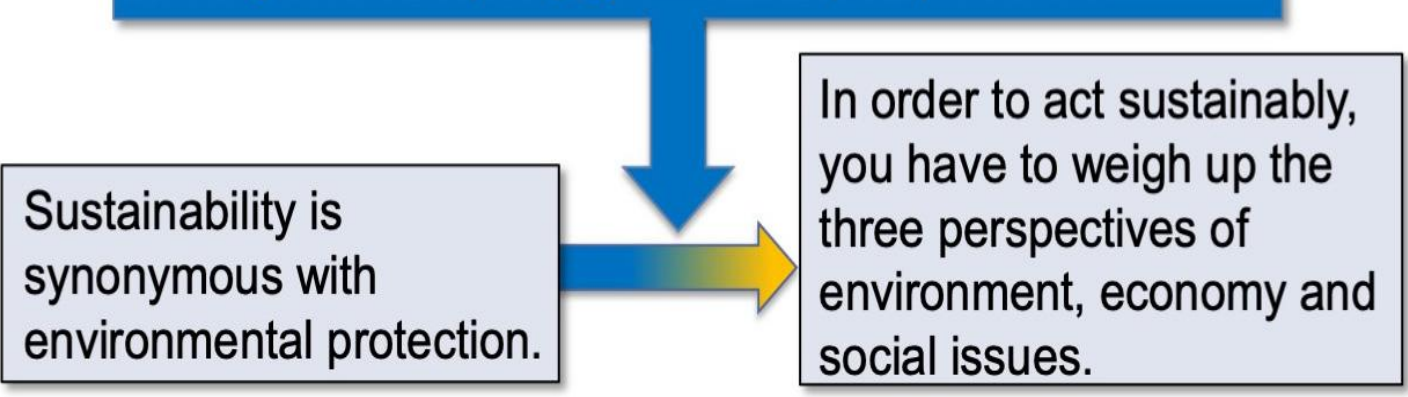

Fig2a-c. Exemplary learning processes in different categories. On the left the retrospectively named conception, on the right the current conception, above the reason for the conceptual change named by the probands.

\section{DISCUSSION}

\subsection{Focus on Affective Components of Behavior}

The concepts identified suggest a differentiated approach of the students to the topic. None of the concepts found is technically completely wrong, although some of them are questionable or worth discussion (e.g. concepts \# 4, 10, 16, 21, 25). Several concepts involve personal assessments such as preferences, morals, and feelings (e.g., Concepts \# 7, 8, 9, 14, 23). Sustainable action is seen as a "worthwhile" goal. Individual probands" feel better" when they have properly separated the garbage, not eaten meat or done something else for the environment. Emotions and affective components are considered to have a huge impact on behavior [23]. And behavior is what counts for sustainability. Hence, many approaches to ESD aim to experience nature authentically in order to initiate positive attitudes towards nature [24]. The great affinity of young people to digital media could also be used in this sense. Accordingly, digital game-based learning and serious games are seen as a promising approach for new teaching and learning methods $[25 ; 26 ; 27]$.

Most of the serious games developed serve to impart knowledge, a minority aims at problem-solving skills, only very few concentrate on attitudes and affective goals or socio-cultural aspects $[28 ; 29]$. Simulations that address sustainability, focused more on sober content (e.g. use of the land [30]) and less on the game flow and affective goals. Other games were not designed as learning games and thus could not be integrated into the classroom or into another learning environment (e.g. "Anno2070"). However, especially in the area of resource management, games and simulations can make a valuable contribution [31]. In addition to imparting knowledge, it therefore seems obvious to focus on the game flow, affective approaches and personal attitudes as well as on action.

\subsection{Causes of Conceptual Changes}

The probands often justified their conceptual changes during the interview without further questions and brought a specific cause into play. But even if you asked them explicitly, you received predominantly the same stated reason: In the educational game, actions elicit immediate feedback (see Fig. 2a-c). For example, buying regional products was rewarded directly with positive effects on the three sustainability indicators (environment, society, economy), while buying imported products was sometimes cheaper but had a negative impact on the indicators. This feedback was combined with optionally available information about the transport routes of the products. In the sense of the competence model for environmental education [32], action-related knowledge and effectiveness knowledge would be built up in this way, namely about relationships that would be difficult to experience in reality. The strength of a simulation game is therefore the immediate feedback on actions that would have non-visible or long-term effects in the real world. Our data accordingly suggest that a digital learning game like "DiLeNa" is basically well suited to positively contribute to ESD at elementary school by linking knowledge and action in combination with immediate feedback. 


\section{CONCLUSiON}

Both sustainability and digital media cover a wide range of topics including important aspects of humanities, social sciences and education. Our project combines education for sustainable development with the digitization of the society. Our results do not answer the question of whether a digital game can convey ESD content better than other media or learning opportunities. We have not compared different settings and do not yet have large scale statistics. Instead, the study offers a good and promising starting point for the implementation of ESD programs using the advantages of digital simulation games, such as immediate feedback, in order to teach sustainable behavior in a simple and effective way at elementary school. We found several learning processes based on specific game elements and game simulation experiences. In conclusion, our data show that a digital educational game can effectively contribute to ESD in elementary schools by linking knowledge and (digital) action in combination with immediate feedback.

However, so that educational games can develop their full potential, preparatory and follow-up lessons are required to embed them as a core element of the curriculum [33]. But there are only a few concepts for integrating serious games into classroom. In particular, the subsequent assessment and reflection has so far only been insufficiently addressed [9]. Although digital learning games are generally seen as a positive enrichment in education, there are still only a few empirical findings on their effects and causes, especially when it comes to embedding such games in the classroom $[28 ; 34 ; 35]$.

\section{ACKNOWLEDGEMENT}

We thank the Joachim Herz Foundation for supporting the project and the game company upjers $\mathrm{GmbH}$ for the excellent cooperation. Free download of the game: https://www.uni-bamberg.de/ nawididaktik/lernspiel-dilena/

\section{REFERENCES}

[1] Eulefeld, G., Bolscho, D., Rode, H., Rost, J., \& Seybold, H. (1993). Entwicklung der Praxis schulischer Umwelterziehung in Deutschland. Kiel: IPN.

[2] Bogner, F. X., \& Wiseman, M. (2004). Outdoor ecology education and pupils' environmental perception in preservation and utilization. Science Education International, 15(1), 27-48.

[3] Unterbruner, U. (2013). Umweltbildung. In H. Gropengießer, U. Harms \& U. Kattmann (Hrsg.), Fachdidaktik Biologie (S. 169-190). Hallbergmoos: Aulis Verlag.

[4] Hüther, G. (2006). Neurobiological approaches to a better understanding of human nature and human values. TD: The Journal for Transdisciplinary Research in Southern Africa, 2(2), 331-343.

[5] Barth, M., Fischer, D., Michelsen, G., Nemnich, C., \& Rode, H. (2012). Tackling the knowledge-action gap in sustainable consumption: insights from a participatory school programme. Journal of Education for Sustainable Development, 6(2), 301-312.

[6] Hamilton, E. R., Rosenberg, J. M., \&Akcaoglu, M. (2016). The substitution augmentation modification redefinition (SAMR) model: A critical review and suggestions for its use. TechTrends, 60(5), 433-441.

[7] Azeiteiro, U. M., Bacelar-Nicolau, P., Caetano, F. J., \&Caeiro, S. (2015). Education for sustainable development through e-learning in higher education: experiences from Portugal. Journal of Cleaner Production, 106, 308-319.

[8] Hwang, G. J., \& Wu, P. H. (2012). Advancements and trends in digital game- based learning research: a review of publications in selected journals from 2001 to 2010. British Journal of Educational Technology, 43(1).

[9] Crookall, D. (2010). Serious games, debriefing, and simulation/gaming as a discipline. Simulation \& gaming, 41(6), 898-920.

[10] Jacob, A., \&Teuteberg, F. (2017). Game-Based Learning, Serious Games, Business Games und Gamification. In S. Strahringer\& Christian Leyh (Hrsg.), Gamification und Serious Games (S. 97-112). Heidelberg: Springer.

[11] Katsaliaki, K., \&Mustafee, N. (2015). Edutainment for sustainable development: A survey of games in the field. Simulation \& Gaming, 46(6), 647-672.

[12] Liarakou, G., Sakka, E., Gavrilakis, C., \&Tsolakidis, C. (2012). Evaluation of serious games, as a tool for education for sustainable development. European Journal of Open, Distance and E-learning, 15(2).

[13] Fosnot, C. T. (2013). Constructivism: Theory, perspectives, and practice. Teachers College Press.

[14] Chi, M. T. (2008). Three types of conceptual change: Belief revision, mental model transformation, and categorical shift. In S. Vosniadou (Ed.), International Handbook of Research on Conceptual Change (pp. 61-82). Taylor \& Francis. 
[15] Strike, K.A., \& Posner, G.J. (1992). A revisionist theory of conceptual change. Philosophy of science, cognitive psychology, and educational theory and practice, 147-176.

[16] Novak, J. D. (2002). Meaningful learning: The essential factor for conceptual change in limited or inappropriate propositional hierarchies leading to empowerment of learners. Science Education, 86(4), 548-571.

[17] Duit, R., \&Treagust, D.F. (1998). Learning in science: From behaviourism towards social constructivism and beyond. In Fraser, B.J., \& Tobin, K. G. (Eds.). International handbook of science education (pp. 325). London: Kluwer Academic Publishers.

[18] Kattmann, U. (2008). Learning biology by means of anthropomorphic conceptions? In M. Hammann, M. Reiss, C. Boulter \& S. D. Tunnicliffe (Eds.), Biology in context: Learning and teaching for the twenty-first century (S. 7-17). London: Institute of Education.

[19] Rockström, J., \& Sukhdev, P. (2016). How food connects all the SDGs. opening key note speech at the 2016 EAT Forum.

[20] Bandura, A. (1994). Self-efficacy. In: V. S. Ramachaudran (Ed.), Encyclopedia of human behavior (Vol. 4, S. 71-81). New York: Academic Press.

[21] Paul, J., Lederman, N.G., \&Groß, J. (2016). Learning experimentation through science fairs. International Journal of Science Education, IJSE, 38(15), 2367-2387.

[22] Seidman, I. (2012). Interviewing as qualitative research: A guide for researchers in education and the social sciences. Teachers College Press.

[23] Dolan, R. J. (2002). Emotion, cognition, and behavior. science, 298(5596), 1191-1194.

[24] Restall, B., \& Conrad, E. (2015). A literature review of connectedness to nature and its potential for environmental management. Journal of environmental management, 159, 264-278.

[25] Connolly, T.M., Boyle, E.A., MacArthur, E., Hainey, T., \& Boyle, J.M. (2012). A systematic literature review of empirical evidence on computer games and serious games. Computers \& Education, 59(2), 661686.

[26] Schaal, S., Schaal, S., \& Lude, A. (2015). Digital Geogames to foster local biodiversity. International Journal for Transformative Research, 3(1), 16-29.

[27] Wouters, P., Van Nimwegen, C., Van Oostendorp, H., \& Van Der Spek, E. D. (2013). A meta-analysis of the cognitive and motivational effects of serious games. Journal of educational psychology, 105(2), 249.

[28] Li, M. C., \& Tsai, C. C. (2013). Game-based learning in science education: A review of relevant research. Journal of Science Education and Technology, 22(6), 877-898.

[29] Schneider, J., \&Schaal, S. (2017). Location-based smartphone games in the context of environmental education and education for sustainable development: fostering connectedness to nature with Geogames. Environmental Education Research, 23, 1-14.

[30] Lindner, M., \& Neubert, P. (2016). LandYOUs - an online game in classroom teaching. In: Rusek, M. (ed.): Project-based education in Science education 13, 87-94. Prague.

[31] Barreteau, O., Le Page, C., \& Perez, P. (2007). Contribution of simulation and gaming to natural resource management issues: an introduction. Simulation \& Gaming, 38(2), 185-194.

[32] Roczen, N., Kaiser, F. G., Bogner, F. X., \& Wilson, M. (2014). A competence model for environmental education. Environment and Behavior, 46(8), 972-992.

[33] Fjællingsdal, K. S., \&Klöckner, C. A. (2019). Gaming Green: The Educational Potential of Eco-A Digital Simulated Ecosystem. Frontiers in Psychology, 10, 2846.

[34] Clark, D. B., Tanner-Smith, E. E., \& Killingsworth, S. S. (2016). Digital games, design, and learning: A systematic review and meta-analysis. Review of educational research, 86(1), 79-122.

[35] Stanitsas, M., Kirytopoulos, K., \&Vareilles, E. (2019). Facilitating sustainability transition through serious games: A systematic literature review. Journal of cleaner production, 208, 924-936. 


\section{AUTHOR'S BIOGRAPHY}

Jürgen Paul studied biology and chemistry at the University of Würzburg in Germany and at the University of Arizona in the USA. After 10 years of teaching at a high school, he now works at the department of science education at the University of Bamberg in Germany. There he is also head of the "Lifelong Learning" division of the Center for Teacher Training.

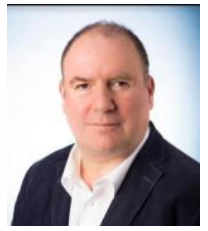

Richard Fry is from the south west of England and did his undergraduate work in Scotland and his post graduate at the Royal Veterinary College in London. After 24 years as an Associate Professor of Natural Sciences with the University of Maryland system, he now lectures at the University of Applied Sciences and Arts in Coburg, Germany.

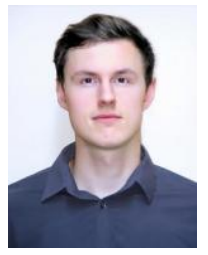

Moritz Schneider studied biology and other subjects at the University of Bamberg in Germany. He is a budding teacher at elementary school, where he and his colleagues tested the serious game DiLeNa, which was used in this study for sustainable development education during science lessons.

Citation: Jürgen Pau, et.al., Effectiveness of Digital Gaming in Education for Sustainable Development" International Journal of Humanities Social Sciences and Education (IJHSSE), vol 7, no. 10, 2020, pp. 128-136. doi: http://dx.doi.org/10.20431/2349-0381.0710016.

Copyright: (C) 2020 Authors. This is an open-access article distributed under the terms of the Creative Commons Attribution License, which permits unrestricted use, distribution, and reproduction in any medium, provided the original author and source are credited. 